\title{
PENGOLAHAN LIMBAH CAIR BATIK MENGGUNAKAN TEKNOLOGI MEMBRAN NANOFILTRASI DI KOTA PEKALONGAN
}

\author{
Kiswanto $^{1 *}$, Laila Nur Rahayu ${ }^{2}$, Wintah $^{3 *}$ \\ ${ }^{1}$ Program Studi Teknik Industri, Fakultas Teknik Universitas Teuku Umar Meulaboh \\ ${ }^{2}$ Program Studi Ilmu Biolagi, Fakultas MIPA Nahdhatul Ulama Purwokerto \\ ${ }^{3}$ Program Studi Ilmu Kesehatan, Fakultas Kesehatan Masyarakat Universitas Teuku Umar \\ Korespondensi : kiswantoanto5@gmail.com, syuga_2006@yahoo.co.id
}

\begin{abstract}
Pekalongan is the most famous batik city in Indonesia. UNESCO was crowned Pekalongan as the most creative batik city. Along with the coronation of Batik city, emerging problems related to the pollution of waste batik that ultimately damage the environment. It needs to be done fast and environmentally friendly batik waste processing. One alternative is the processing of batik waste using membrane technology. To know the performance of membrane nanofiltration in color allowance, $C O D, B O D, T S S$, and metal $P b$ used batik liquid waste with different concentrations. This research was conducted to analyse the influence of pressure (4, 5, and 6 bar) against flux and the degree of windection of each of the parameters. The optimum pressure of membrane nanofiltration for all parameters is 6 bar. The results showed that the results of the rejection of colorants, COD, BOD, TSS and $\mathrm{Pb}$ respectively without dilution, 10 times dilution, 20 times dilution, 30 times in successive dilution is (98,29\%-99.87\%), (92,10-100\%), (100\%), (99,25-100\%), (95,25-100\%). The results showed that the color allowance, COD, BOD, TSS and Pb Metal had fulfilled the quality standards for the optimum pressure of 6 bar according to Ministry of Environment Regulation No. 5 year 2004 and Local Regulations of Central Java No. 5 year 2012. Potential of membrane nanofiltration technology can be used for the processing of batik liquid waste.
\end{abstract}

Keywords: Batik Waste, Nanofiltration, Pressur, Color

\section{PENDAHULUAN}

Batik telah diakui oleh Badan Perserikatan Bangsa Bangsa Urusan Kebudayaan (UNESCO) sebagai warisan budaya dunia yang berasal dari Indonesia pada tanggal 2 oktober 2009. Pengakuan ini diberikan UNESCO dengan melihat berbagai upaya yang dilakukan oleh Indonesia, terutama karena penilaian terhadap keragaman motif batik yang penuh makna filosof mendalam. Batik merupakan produksi tekstil yang dapat dijumpai di seluruh Indonesia, salah satu kota batik terbesar di Indonesia adalah Kota Pekalongan Jawa Tengah. Produksi batik di Kota Pekalongan yang terus meningkat menyebabkan terjadinya pencemaran air pada sungai-sungai di Wilayah Kota Pekalongan terutama di kawasan sentra industri batik (Lemlit UNDIP, Dinas Penataan Kota dan Lingkungan Hidup Kota Pekalongan, 2008).

Industri batik di Kota Pekalongan merupakan salah satu penghasil limbah cair yang berasal dari proses pewarnaan. Selain kandungan zat warnanya tinggi, limbah industri batik dan tekstil juga mengandung bahan-bahan sintetik yang sukar larut atau sukar diuraikan. Pada proses produksi pembuatan batik diperlukan sumber air serta bahan kimia yang berupa bahan organik dan anorganik yang dapat mengakibatkan beberapa parameter kualitas air limbah batik seperti BOD, COD, TDS, dan TSS kadarnya menjadi tinggi (Subki et al., 2011; Kurniawan et al., 2013), sehingga parameter-parameter tersebut kadarnya melebihi baku mutu yang yang telah ditetapkan (Perda Prop Jawa Tengah No. 
5/2012), hal ini menunjukkan bahwa limbah cair batik tersebut harus diolah terlebih dahulu sebelum dibuang ke sungai.

Jika industri batik tersebut membuang limbah cair, maka aliran limbah tersebut akan melalui perairan di sekitar pemukiman. Dengan demikian mutu lingkungan tempat tinggal penduduk menjadi turun. Limbah tersebut dapat menaikkan kandungan organik seperti COD, BOD,TSS dan pH. Jika hal ini melampaui ambang batas yang diperbolehkan, maka gejala yang paling mudah diketahui adalah matinya organisme perairan (Al-kdasi, 2004).

Kinerja IPAL batik komunal di Kota Pekalongan dengan proses lumpur aktif dan proses biologi-fitoremediasi lahan basah (wetland) belum bisa menurunkan kadar pencemar sesuai baku mutu, jumlah IPAL yang ada juga belum bisa mengolah seluruh limbah cair batik yang dihasilkan sehingga kadar BOD, COD, dan TSS di sungai-sungai di Kota Pekalongan masih lebih tinggi bila dibandingkan dengan Peraturan Pemerintah RI Nomor 82 tahun 2001 (Lemlit UNDIP, Dinas Penataan Kota dan Lingkungan Hidup Kota Pekalongan, 2008).

Pada proses pewarnaan batik, zat warna yang paling banyak digunakan pada industri batik antara lain zat warna turunan benzonaphthalene, zat warna turunan azonaphthalene, zat warna langsung (alami) dan zat warna reaktif (Sumantri et al., 2006). Menurut Al-kdasi (2004) berdasarkan struktur kimianya zat warna dibagi menjadi bermacam-macam, antara lain: zat warna nitroso, nitro, azo, stilben, difenil metana, trifenil metana, akridin, kinolin, indigoida, aminokinon, anin dan indofenol. Namun, secara garis besar zat warna digolongkan menjadi dua golongan yaitu zat warna alami dan zat warna sintetik. Salah satu contoh struktur zat warna yang digunakan salah satu contoh zat warna yang banyak dipakai industri tekstil adalah remazol black, red dan golden yellow. Dalam pewarnaan, senyawa ini hanya digunakan sekitar 5\% sedangkan sisanya yaitu $95 \%$ akan dibuang sebagai limbah. Senyawa ini cukup stabil sehingga sangat sulit untuk terdegradasi di alam dan berbahaya bagi lingkungan apalagi dalam konsentrasi yang sangat besar karena dapat menaikkan COD (Chemical Oxygen Demand).

Permasalahan pencemaran limbah cair batik ke permukaan air di sungai Pekalongan yang dihadapi saat ini adalah selain kurangnya efisiensi pengolahan IPAL komunal yang masih di atas baku mutu Peraturan Menteri Lingkungan Hidup No. 5 Tahun 2014, Permenkes 416 Tahun 1990, dan Perda Jateng No. 5 Tahun 2012.

Untuk mendegradasi dalam penyisihan zat warna, COD, BOD, TSS, kekeruhan, logam berat dan padatan terlarut dibutuhkan membran nanofiltrasi (Bhuyar et al.,2014). Berdasarkan pengolahan limbah cair batik yang di Kota Pekalongan menjadi sungai yang bersih dibutuhkan pengolahan yang cepat, efisien dan ramah lingungan.

Memperhatikan dampak yang diakibatkan oleh limbah cair industri batik tersebut metode membran nanofiltrasi menjadi pilihan dalam pengolahan limbah cair batik di Kota Pekalongan.

\section{TUJUAN PENELITIAN .}

Tujuan penelitian pengolahan limbah batik cair ini adalah untuk :

2.1 Untuk mengetahui kinerja membran Nanofiltrasi dalam penyisihan warna, COD, $\mathrm{BOD}$, TSS, dan logam $\mathrm{Pb}$ digunakan limbah cair batik dengan konsentrasi yang berbeda.

2.2 Penelitian ini dilakukan untuk menganalisis pengaruh tekanan (4, 5, dan 6 bar) terhadap Fluks dan tingkat rejeksi dari masing-masing dari setiap parameter. 
2.3 Mengolah limbah cair batik menjadi air bersih untuk dapat digunakan kembali.

\section{TINJAUAN PUSTAKA}

\subsection{Air Limbah}

Air limbah juga dikenal sebagai sewage, mula-mula dari limbah rumah tangga, manusia dan binatang, tapi kemudian berkembang selain dari sumber-sumber tersebut juga air limbah berasal dari kegiatan industri, run off, infiltrasi air bawah tanah. Air limbah pada dasarnya 99,94\% berasal dari sisa kegiatan, sedang $0,06 \%$ berasal dari material terlarut oleh proses alam (Lin dalam Aris, 2006). Sumber air limbah dikelompokkan menjadi yaitu; air limbah domestik dan air limbah non domestik, salah satu contoh dari air limbah non domestik adalah kegiatan industri batik.

\subsection{Air Limbah Batik}

Industri batik merupakan salah satu penghasil limbah cair yang berasal dari proses pewarnaan, selain kandungan zat warnanya sangat tinggi, limbah industri batik juga mengandung bahan-bahan sintetik yang sukar diuraikan. Setelah proses pewarnaan selesai akan dihasilkan limbah cair yang berwarna keruh dan pekat, biasanya warna air limbah batik tergantung pada zat warna yang digunakan. Limbah cair batik yang berwarna pekat dapat menyebabkan masalah terhadap lingkungan (Lestari, 2017).

Limbah zat warna yang dihasilkan dari industri batik umumnya merupakan senyawa organik non-biodegradable yang dapat menyebabkan pencemaran lingkungan terutama perairan. Jika industri batik limbah tersebut dapat menaikkan kadar COD (Chemical Oxygen Demand). warna yang banyak dipakai industri batik adalah remazol black, red dan golden yellow. Dalam perwarnaan, senyawa ini hanya digunakan sekitar 5\% sedangkan sisanya 95\% akan dibuang sebagai limbah. Senyawa ini cukup stabil sehingga sangat sulit untuk terdegradasi di alam dan berbahaya bagi lingkungan apalagi dalam konsentrasi yang sangat besar karena dapat menaikkan COD (Lestari, 2017).

\subsection{Karakteristik Limbah Cair}

Karakteristik limbah cair yang dihasilkan industri tekstil sangat erat hubungannya dengan bahan-bahan yang digunakan dalam tahapan proses pembuatan tekstil. Karakteristik dan baku mutu limbah cair industri tekstil disajikan seperti pada tabel di bawah ini.

Tabel 1 Karakteristik dan Baku Mutu Limbah Cair Industri Tekstil

\begin{tabular}{lll}
\hline Parameter & Satuan & $\begin{array}{l}\text { Kadar maksimum menurut Kepmen LH } \\
\text { No. 51/MENLH/10/1995 }\end{array}$ \\
\hline Biochemical oxygen demand (BOD) & $\mathrm{Mg} / \mathrm{L}$ & 60,0 \\
Chemical oxygen demand (COD) & $\mathrm{Mg} / \mathrm{L}$ & 150,0 \\
Total suspended solid (TSS) & $\mathrm{Mg} / \mathrm{L}$ & 50,0 \\
pH & - & $6,0-9,0$ \\
Warna & Pt-Co & - \\
\hline (Sumber : KepMen LH No. 51/MENLH/10/1995) &
\end{tabular}

\subsection{Teknologi Membran}

Membran merupakan suatu lapisan tipis yang bersifat permeable atau semipermeable yang menghalangi unsur unsur dengan ukuran tertentu untuk melewatinya. Membran menjadi penghalang yang mengontrol transportasi molekul 
molekul sehingga terbentuklah permeat yang terbebas dari molekul molekul pengotor. Performa suatu membran ditentukan oleh dua faktor sederhana yaitu fluks (kecepatan aliran permeat) dan selektivitas membrane (Hughes, 1992).

Membran proses termasuk mikrofiltrasi (MF), ultrafiltrasi (UF), nanofiltrasi (NF) dan reverse osmosis (RO) telah menjadi alat penting dalam pengelolaan air, karena lebih efisiensi telah terbukti dari teknis dan ekonomis, serta ekologi untuk beberapa waktu sekarang. Hal ini sebagian didasarkan pada hasil yang diperoleh selama operasi sistem reverse osmosis yang dikembangkan pada hari-hari awal teknologi ini untuk desalinasi air laut, dengan proses ini menjadi salah satu tonggak paling penting dalam sejarah teknologi membran menghasilkan paten yang diberikan untuk pertama spiral-luka-elemen pada tahun 1964 (Cheryan, 1998).

Proses membran yang digunakan saat ini untuk berbagai pose yang berbeda, tapi terutama untuk mengatasi kelangkaan air dan untuk mencegah polusi air, dimana pilihan jenis proses harus terhenti sebagai langkah utama atau dalam kombinasi dengan teknologi lainnya tergantung pada jenis komponen atau kontaminan, kembali spectively, dipisahkan dari air untuk diperlakukan, dan persyaratan kualitas yang dikenakan untuk air yang dihasilkan. Penggunaan teknologi membran, pengolahan air jangka panjang dipandang terdiri kedua bidang pengelolaan air konvensional yang fokus dan didasarkan pada topik cluster air minum kualitas air pengolahan industri air limbah (Peters, 2010).

\section{METODE PENELITIAN}

Penelitian ini bersifat eksperiment skala laboratorium di Laboratorium Teknik Lingkungan UNDIP dan di Laboratorium Membran Riset Center (MeR-C) UNDIP. Sampel limbah cair batik diambil dari home Industri batik cap di Banyuurip Ageng Kecamatan Pekalongan Selatan Kota Pekalongan.

\subsection{Bahan}

Bahan yang digunakan adalah air limbah batik Rumah Tangga dengan karakteristik seperti Tabel 2, kertas saring, dan membran Nanofiltrasi dengan spesifikasi seperti Tabel 3.

Tabel 2 Karakteristik Air limbah batik rumah tangga

\begin{tabular}{ll}
\hline Parameter & Konsentrasi \\
\hline Warna (Pt-Co) & 29721,7 Pt-Co \\
COD & 12063,33 \\
BOD & 3739,53 \\
TSS & 8420 \\
$\mathrm{~Pb}$ & 3,015 \\
\hline
\end{tabular}

Tabel 3 Karakteristik membran NF270 (DOW Filmtec)

\begin{tabular}{ll}
\hline Material & Komposit Poliamida \\
\hline Tekanan Maksimum (bar) & 41 \\
Suhu Maksimum $\left({ }^{\circ} \mathrm{C}\right)$ & 45 \\
Rentang pH & $2-11$ \\
Rejeksi MgSO & $(\%)$ \\
\hline
\end{tabular}

\subsection{Alat}

Alat yang digunakan diantaranya adalah $\mathrm{COD}$ (HACH dengan ketelitian 0,001), spektofotometer (Thermo Scientific dengan ketelitian 0,001), Corong Pisah, Neraca Analitik, dan Unit Membran seperti gambar 1. 


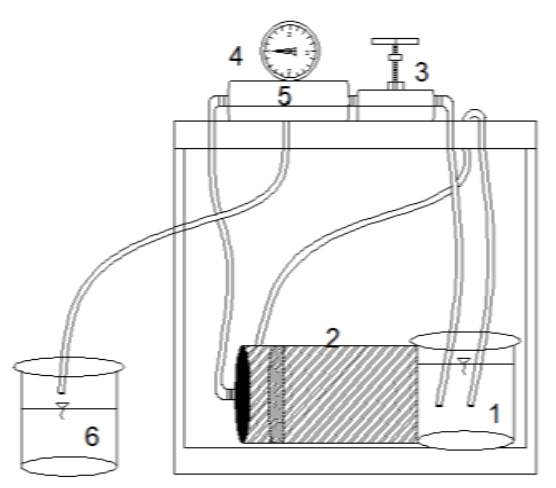

Gambar 1 Skema unit membran dengan operasi cross-flow

Keterangan:

1. Sampel air limbah batik dalam gelas beker $1000 \mathrm{ml}$

2. Pompa Reverse Osmosis dengan

Spesifikasi

Nominal Flow Rate : 1.0 LPM

Max Pump output : 110 Psi

Max Inlete Pressure : 90 Psi

Voltage : 24 VDC

3. Pengatur Tekanan

4. Manometer Tekanan

5. Tempat peletakan membran untuk dilakukan pengujian.

6. Permeat (hasil pengolahan dengan membran.

\subsection{Prosedur Penelitian}

Penelitian ini dilakukan dengan menggunakan membran Nanofiltrasi (NF) dengan ukuran pori $180 \mathrm{kDa}$ pada tekanan 4,5, 6 Bar. Membran ini didapat dari Alfa Laval, Sweden dan dicetak dengan ukuran diameter 4,22 cm lalu diilakukan kompaksi selama 30 menit untuk menstabilkan pori dan struktur membran.

Prefiltrasi menggunakan kertas saring dilakukan sebelum limbah masuk ke dalam unit membran. Hal ini bertujuan untuk mengurangi jumlah padatan tersuspensi yang dapat meningkatkan terjadinya penyumbatan membran. Penelitian dilaksanakan secara cross flow filtration dan dilakukan selama 3 jam dengan waktu pengambilan permeat setiap 15 menit untuk diukur permeabilitasnya.

\subsection{Analisa Hasil}

Analisa yang dilakukan yaitu fluks dan rejeksi parameter, warna, COD, BOD, TSS, dan $\mathrm{Pb}$.

\subsubsection{Analisa Fluks dan Rejeksi membran :}

a) Perhitungan Fluks

Umpan dialirkan ke filtrasi membran pada tekanan 4 bar, 5 bar dan 6 bar selama 120 menit. Pengambilan sampel dilakukan setiap 10 menit dengan lama penampungan selama 5 menit, jadi total 15 menit. Membran ini didapat dari Alfa Laval, Sweden dan dicetak dengan ukuran diameter 4,22 cm lalu diilakukan kompaksi selama 30 menit untuk menstabilkan pori dan struktur membran. 
Penelitian dilaksanakan secara cross flow filtration dan dilakukan selama 3 jam dengan waktu pengambilan permeat setiap 15 menit

Fluks dihitung dari data volume sampel (V), waktu pengambilan sampel dan luas permukaan membran (A). Dari data volume dan waktu pengambilan sampel (t) maka diperoleh laju alir volumetrik permeate (Q) yang dihasilkan $(\mathrm{Q}=\mathrm{V} / \mathrm{t})$. Setelah diperoleh data-data tersebut kemudian dilakukan perhitungan fluks sebagai berikut;

$\mathrm{J}=\frac{1}{\mathrm{~A}} \mathrm{Q}$

b) Rejeksi Membran

Analisa rejeksi dilakukan dengan membandingkan konsentrasi parameter yang terkandung dalam umpan produced water dan permeat yang dihasilkan. Persamaan perhitungan rejeksi adalah sebagai berikut;

$\% R=1-\frac{\mathrm{cp}}{\mathrm{cf}} \times 100 \%$

\subsection{Metode Analisis}

Parameter Warna, COD dan BOD diuji berdasarkan SNI 06-6989.3-2004 menggunakan spektrofotometer (Genesys 10S UV-Vis produksi Thermo Scientific USA) pada panjang gelombang $420 \mathrm{~nm}$. Parameter TSS diuji secara gravimetri berdasarkan SNI 06-6989.3-2004. Parameter Pb diuji berdasarkan SNI 06-6989.42004 dengan alat AAS (model 210 VGP produksi Buck Scientific USA) pada panjang gelombang $248 \mathrm{~nm}$.

\section{HASIL DAN PEMBAHASAN}

\subsection{Uji Fluks Umpan}

Profil fluks umpan berupa air limbah batik home industri dengan perlakuan tanpa pengenceran, 10 kali pengenceran, 20 kali pengenceran dan 30 kali pengenceran. Kemudian difiltrasi dengan membran Nanofilrasi saat melewati membran Nonofiltrasi disajikan pada gambar 2

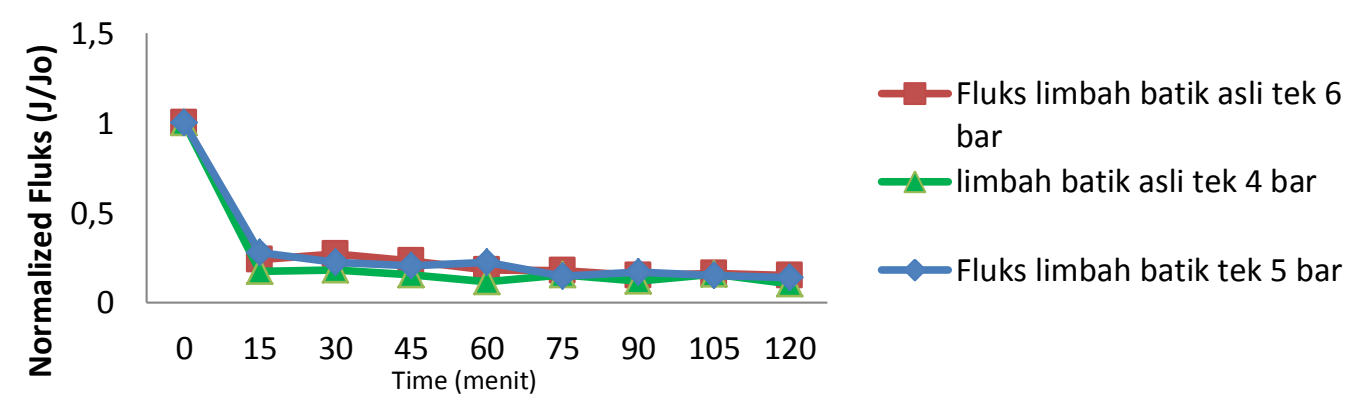

Gambar 2 Profil Fluks (J/J0) Pada Filtrasi limbah batik Menggunakan Membran Nanofiltrasi

Gambar 2 menunjukkan profil fluks ternormalisasi yang secara umum menurun secara signifikan seiring berjalannya waktu. Penurunan fluks ini diakibatkan oleh fouling dan konsentrasi polarisasi. Almazan et al (2015), mengatakan bahwa konsentrasi polarisasi terjadi akibat akumulasi solut yang tertahan pada permukaan membran sehingga mengakibatkan penurunan fluks. 


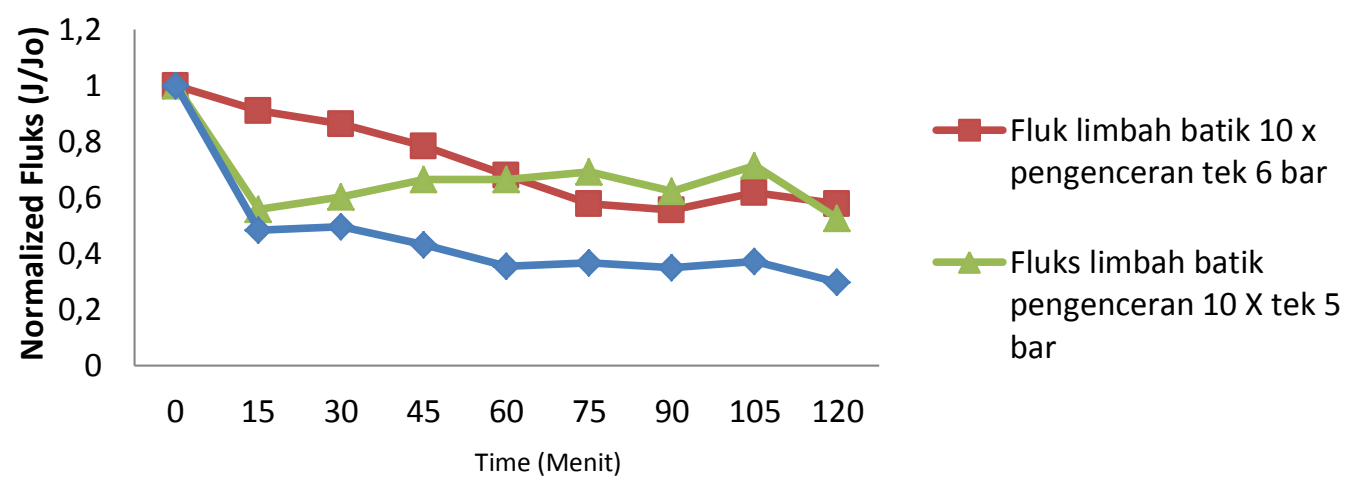

Gambar 3 Grafik pengaruh Tekanan Terhadap Relative Fluks Larutan limbah batik dengan 10 kali pengenceran

Pada Grafik 3 profil fluks ternormalisasi terjadi penurunan pada tekanan 4 bar pada 10 kali pengenceran. Pada 10 kali pengenceran terjadi penurunan fluks paling tajam terjadi pada menit 15 untuk semua tekanan. Pada tekanan 6 bar dan 4 bar terjadi penurunan secara konsisten sampai menit ke 90. Berbeda halnya dengan tekanan 5 bar yang terjadi kenaikan secara konsisten sampai menit ke 75 selanjutnya mengalai penurunan. Penurunan fluks ini terjadi karena adanya fouling (Schafer et al, 2004) dan Konsentrasi Polarisasi (Almazan et al, 2015) pada permukaan membran.
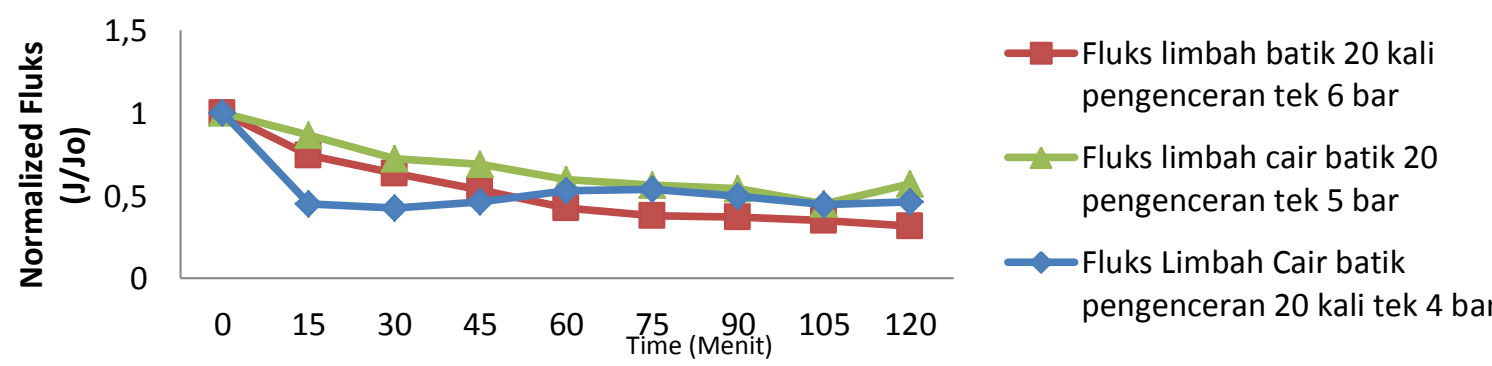

Gambar 4 Grafik pengaruh Tekanan Terhadap Relative Fluks Larutan limbah batik dengan 20 kali pengenceran

Pada Grafik 4 profil fluks ternormalisasi terjadi penurunan pada tekanan 6 bar pada 20 kali pengenceran. Pada 20 kali pengenceran terjadi penurunan fluks paling tajam terjadi pada menit 15 menit untuk semua tekanan. Pada tekanan 6 bar dan 5 bar terjadi penurunan secara konsisten sampai menit ke 120. Berbeda halnya dengan tekanan 4 bar yang terjadi kenaikan pada menit ke 45 sampai menit ke 75 selanjutnya mengalai penurunan hingga menit ke 120. Penurunan fluks ini terjadi karena adanya fouling (Schafer et al., 2004) dan Konsentrasi Polarisasi (Almazan et al., 2015) pada permukaan membran.

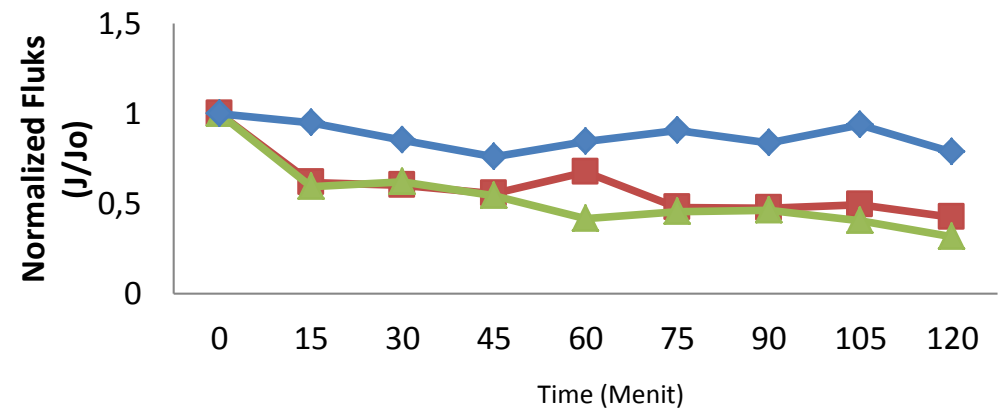

-Fluks limbah cair batik pengenceran 30 kali tek 6 bar

Fluks limbah cair batik pengenceran 30 kali tek 5 bar

Fluks limbah cair batik pengenceran 30 kali tek 4 bar

Gambar 5 Grafik pengaruh Tekanan Terhadap Relative Fluks Larutan limbah batik dengan 30 kali pengenceran 
Pada Grafik 5 profil fluks ternormalisasi terjadi penurunan pada semua tekanan pada 15 menit. Pada 30 kali pengenceran justru fluks yang tertinggi terjadi pada tekanan 4 bar. Pada 30 kali pengenceran terjadi penurunan fluks paling tajam terjadi pada menit 15 menit untuk semua tekanan. Pada tekanan 6 bar dan 5 bar terjadi penurunan secara konsisten sampai menit ke 120. Berbeda halnya dengan tekanan 4 bar yang terjadi kenaikan pada menit ke 45 sampai menit ke 75 selanjutnya mengalai Fluktuatif hingga menit ke 120. Penurunan fluks ini terjadi karena adanya fouling (Schafer et al., 2004) dan Konsentrasi Polarisasi (Almazan et al., 2015) pada permukaan membran.

Dari keempat gambar diatas terlihat bahwa penambahan tekanan berpengaruh terhadap penurunan fluks. Semakin tingginya tekanan, memungkinkan umpan akan melewati membran secara cepat dan semakin banyaknya foulan yang terakumulasi pada permukaan membran maupun struktur membran sehingga menyebabkan penyumbatan pori yang lebih cepat dibandingkan pada tekanan rendah (Zhou, 2010). Lamanya waktu operasi juga mempengaruhi jumlah fluks yang dihasilkan. Semakin lamanya waktu, maka fluks yang dihasilkan akan semakin kecil. Menurut Mulder (1996), hal tersebut disebabkan oleh fouling yang termasuk didalamnya konsentrasi polarisasi, adsorpsi, formasi pembentukan lapisan gel, dan penyumbatan pori.

\subsection{Rejeksi Membran}

Kinerja membran juga ditentukan oleh kemampuan rejeksi terhadap beberapa parameter yaitu Warna, COD, BOD, TSS, Pb.

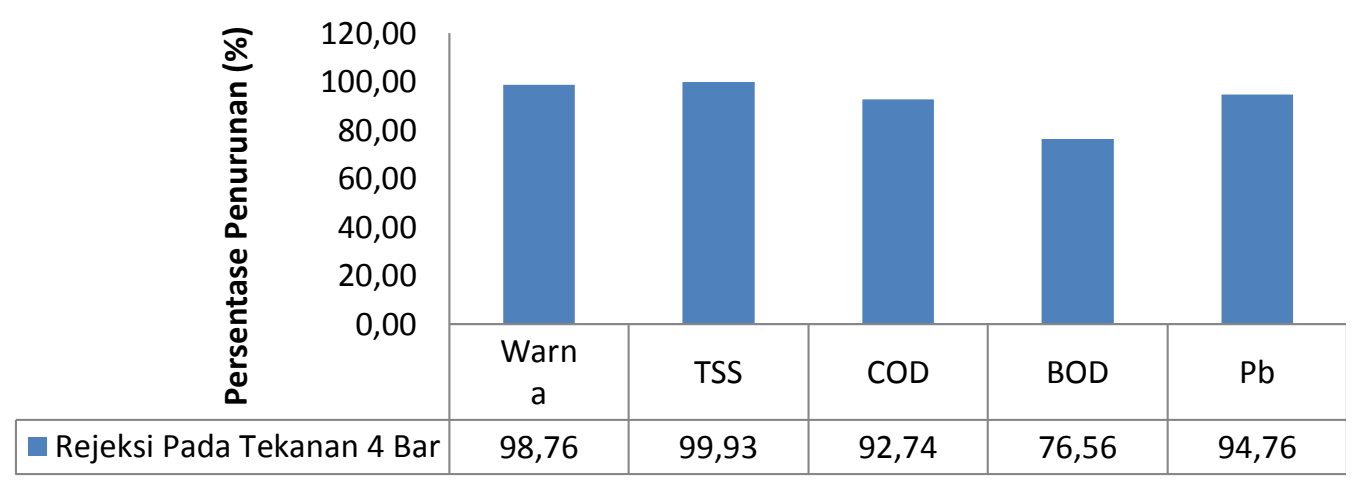

Gambar 6 Rejeksi parameter Warna, TSS, COD, BOD, dan Pb pada tekanan 4 Bar

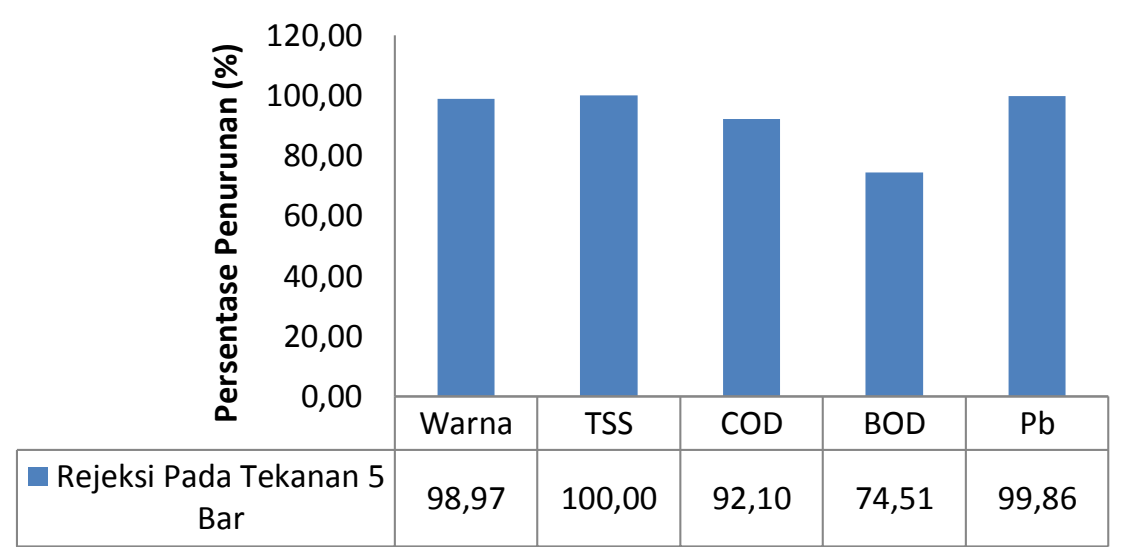

Gambar 7. Rejeksi parameter Warna, TSS, COD, BOD, dan Pb pada tekanan 5 Bar 


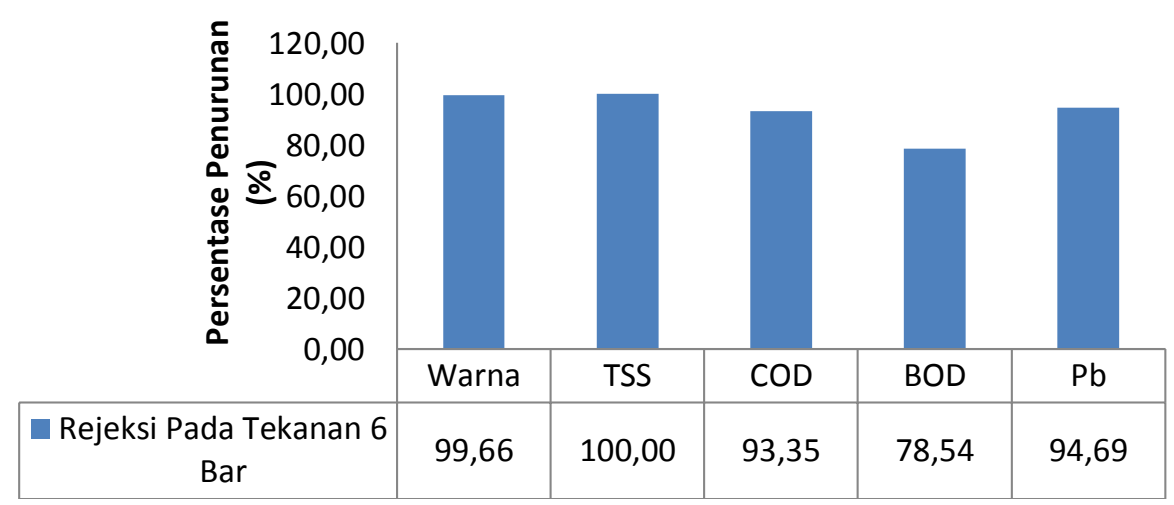

Gambar 8 Rejeksi parameter Warna, TSS, COD, BOD, dan Pb pada tekanan 6 Bar

Pada gambar 6-8 dapat dilihat bahwa tekanan tidak mempengaruhi nilai rejeksi secara signifikan, karena persen rejeksi memiliki nilai hampir sama. Proses penyisihan pada zat warna terjadi secara sieving mechanism/size exsclusion. Proses rejeksi zat warna dapat terjadi karena zat warna memiliki berat molekul 602,59 g/mo, dimana berat molekul tersebut lebih besar dari pori membran Nonofiltrasi NF 270 yaitu 180 Da(Arlabs , 2012). Hal yang sama juga disampaikan oleh Wang, et al., (2007), apabila ukuran partikel lebih besar dari pori membran maka proses penyisihan dapat terjadi. Sesuai dengan penelitian yang dilakukan oleh Aoni, et al., (2012), bahwa rejeksi warna lebih dari $98 \%$ pada seluruh kisaran tekanan. Hasil rejeksi sesuai dengan penelitian Zaghbani,et al., (2009) yaitu rejeksi warna lebih dari 90\%. Tekanan 6 bar merupakan tekanan dengan persen rejeksi tertinggi, sehingga pada tekanan 6 bar konsentrasi warna hampir mencapi $100 \%$.

Rejeksi COD dan BOD dicapai rejeksi teendah pada tekanan 4 bar dan tertinggi pada tekanan 6 bar. Kenaikan rejeksi pada berbagi tekanan tidak begitu signifikan. Untuk rejeksi COD dan BOD menggunakan membran Nanofiltrasi lebih tinggi dibandingkan membran mikrofiltrasi dan ultrafiltrasi sesuai dengan penelitian yang dilakukan oleh (Boussu,2007) bahwa semakin kecil ukuran pori maka tingkat rejeksi parameter COD dan BOD akan meningkat. Fenomena ini dikarenakan zat organik yang berukuran lebih besar dibandingkan pori membran akan tertahan pada pori membran sehingga kandungan zat organik dalam permeat berkurang. Faktor lain yang mempengaruhi tingkat rejeksi parameter COD dan BOD adalah tekanan. Kenaikan tingkat rejeksi pada membran Nanofiltrasi semakin tinggi tekanan mengakibatkan semakin cepatnya terbentuk fouling pada permukaan dan struktur membran sehingga dapat memperkecil ukuran pori membran dan meningkatkan kemampuan membran untuk merejeksi parameter COD (Widyasmara, 2013).

Membran nanofiltrasi mampu menyisihkan TSS dengan tingkat rejeksi mencapai $100 \%$ pada semua tekanan operasi. Hal ini juga sesuai dengan hasil penelitian Ortega (2008), bahwa tingkat rejeksi membran Nanofiltrasi terhadap penyisihan TSS mencapai $100 \%$. Kualitas permeat hasil filtrasi dibandingkan dengan baku mutu Perda Jateng No. 5 Tahun 2012 dari semua parameter yang diuji pada tiga tekanan operasi $(4,5$, dan 6 bar) memenuhi baku mutu untuk parameter TSS.

Untuk pemisahan logam $\mathrm{Pb}$ pada membran Nanofiltrasi juga terjadi karena interaksi elektrostatik antara ion dan permukaan membran. Menurut Tu (2013), ketika membran dikontakkan dengan ion $\mathrm{Pb}$, densitas muatan permukaan membran menjadi positif. Membran Nanofiltrasi yang memungkinkan membuat membran bermuatan 
positif, negatif, atau netral. Pemisahan berdasarkan ukuran pori juga berperan dalam pemisahan $\mathrm{Pb}$.

\section{SIMPULAN DAN SARAN}

\subsection{Kesimpulan}

Membran NF270 terbukti mampu menyisihkan zat warna, COD, BOD, TSS dan logam $\mathrm{Pb}$. Hasil penelitian menunjukan hasil rejeksi dari zat warna, COD, BOD, TSS dan $\mathrm{Pb}$ berturut-turut tanpa pengenceran, 10 kali pengenceran, 20 kali pengenceran, 30 kali pengenceran berturut-turut adalah (98,29\%-99,87\%),(92,10$100 \%),(100 \%),(99,25-100 \%),(95,25-100 \%)$.

Hasil penelitian menunjukkan bahwa penyisihan warna, COD, BOD, TSS dan logam $\mathrm{Pb}$ sudah memenuhi baku mutu untuk tekanan optimum 6 bar sesuai dengan Permen LH No.5 tahun 2004 dan Perda Jateng No.5 Tahun 2012. Teknologi membran Nanofiltrasi dapat diaplikasikan untuk pengolahan limbah cair batik dengan ketentuan harus dilakukan pretreatment terlebih dahulu. Tujuan pretreatment adalah untuk mengurangi polutan dan padatan terlarut dan membantu proses kinerja membran.

\subsection{Saran}

Penelitian ini memberikan pengetahuan dasar untuk potensi teknologi membran untuk pengolahan limbah cair batik menggunakan teknologi membran. Namun demikian, agar dapat diaplikasikan dalam skala komersial, diperlukaan perhitungan penelitian dalam skala pilot projek dalam pemanfaatan kembali limbah cair batik dapat digunakan kembali sebagai air bersih. Selain itu perlu sinergisitas unsur pentahelix yaitu peran pemerintah, akademisi, asosiasi, komunitas, dan media.

\section{DAFTAR PUSTAKA}

Al-kdasi, A., Idris, A., Saed, K.,dan Guan, C.T. 2004. Treatment of textile wastewater byadvanced oxidation processes. Global Nest the Int. J. 6: 222-230.

Almazan, J.E., Dondiz, E.M.R., Rajal, V.B., and Vidaurre, E.F.C. 2015. Nanofiltration of Glucose : Analysis of Parameters and Membrane Characterization. Journal of Chemical Engineering Research and Design. 94: 485-493.

Aouni A., Fersi C., Cuartas-Uribe B., Bes-Pia A., Alcaina-Miranda M.I., Dhahbi M. 2012. Reactive dyes rejection and textile effluent treatment study using ultrafiltration and nanofiltration processes. Journal of Desalination 297: 87-96.

Aris, Mukimin. 2006. Pengolahan Limbah Industri Berbasis Logam Dengan Teknologi Elektrokoagulasi Flotasi. Program Studi Ilmu Lingkungan. Universiras Diponegoro. Semarang

Arlabs, $\quad$ Ltd. 2012. Solubilised $\quad$ Brown http://www.worlddyevariety.com/vatdyes/solubilised-vat-brown-5.html.

Bhuyar, K.D., Loharkar, K.A., and Solanki, R.2014. Design and Fabrication of Nanofiltration Unit: A Review. International Journal of Innovations in Engineering and Technology Vol. 4, ISSBN: 2319-1058.

Boussu,K. 2007.Applicability of Nanofiltration in Carwash Industry. Separation and Purification Technology, 54:139-146.

Cheryan, M.N.R. 1998. Membrane Processing Of Oily Streams. Wastewater Treatment And Waste Reduction. Journal Of Membrane Science, 151:13-28.

Hughes., S.1992. Industrial Membran Separation Technology. Blackie Academic And Professional. Glasgow. 
Kepmen LH No. 51/MENLH/10/1995

Kurniawan, W.M., Purwanto, P., dan Sudarno, S. 2013. Strategi Pengelolaan Air Limbah Sentra UMKM Batik yang Berkelanjutan di Kabupaten Sukoharjo. Jurnal Ilmu Lingkunga, 11 (2): 62 -72.

Lembaga Penelitian Undip dan Dinas Penataan Kota, dan Lingkungan Hidup Kota Pekalongan. 2008. Laporan Akhir Kegiatan Penyusunan Strategi Pengelolaan Kali Pekalongan tahun 2008.

Lestari, N.D. dan Tuhu, A. 2017. Penurunan TSS Dan Warna Limbah Industri Batik Secara Elektro Koagulasi. Jurnal Ilmiah Teknik Lingkungan, 6 (1): 37-38.

Mulder,M.1996. Basic Principle Of Membrane Technology. KluwerAcademic Publishers.Netherlands.

Ortega, L.M., Lebrun, R., Blais, J.F., andAusler, R. 2008. Removal of Metal Ions From An Acidic Leachate Solution by Nanofiltration Membranes. Journal of Desalination. 227: 204-216.

Peraturan Daerah Propinsi Jawa Tengah Nomor 5 Tahun 2012 tentang Perubahan atas Peraturan Daerah Provinsi Jawa Tengah Nomor 10 Tahun 2004 Tentang Baku Mutu Air Limbah.

Peraturan Daerah Provinsi Jawa Tengah Nomor 5 Tahun 2012. Baku Mutu Air Limbah. Peraturan Menteri Kesehatan Nomor: 416/MEN.KES/PER/IX/1990.Syarat-syarat dan Pengawasan Kualitas Air.

Peraturan Menteri Lingkungan Republik Indonesia Hidup No 5 Tahun 2014. Baku Mutu Air Limbah.

Peters, T.2010. Membrane Technology For Water Treatment, 8: 1233-1240.

Subki, N.S. and Rohasliney, H. 2011. A Preliminary Study on Batik Effluent in Kelantan State: A Water Quality Perspective. International Conference on Chemical, Biological and Environment Sciences (ICCEBS'2011). Bangkok Dec., 2011.

Schafer, A.I., Andritsos, N., Karabellas, A.J., Hoek, E.M.V., Schneider, R., andNystrom, M. 2004. Fouling in Nanofiltration in: Nanofiltration-Principles and Applications, Chapter 20: 169-239.

Sumantri, I., Sumarno, A., Nugroho., Istad.i, dan Buchori, L. 2006.Pengolahan Limbah Cair Industri Kecil Batik dengan Bak Anaerobik Bersekat (Anaerobic Baffled Reaktor). Undip Semarang.

Tu, N.P. 2013. Role of Charge Effect During Membrane Filtration. Disertasi. Universiteit Gent.Belgia.

Wang, Kai Yu, T., Chung, R. and Rajagopalan. 2007. Novel Polybenzimidazole (PBI) Nanofiltration Membranes for the separation of Sulfate and Chromate from High Alkalinity Brine to Fasilitate the Chlor-Alkali Process. Industrial and enginering chemistry research, 46(5): 1572-1577.

Widyasmara,M., Kusuma D., dan Cindika. 2013.Potensi Membran Mikrofiltrasi dan Ultrafiltrasi Untuk Pengolahan Limbah Cair Berminyak. Teknologi Kimia dan Industri UNDIP, 2 (2): 29-30.

Zaghbhani, Narjess, A., Hafiane, and Dhabi, M. 2009. Removal of Eriochrome Blue BlackR from Wastewater Using Micellar-Enhanced Ultrafiltration. Laboratoire Eau et Technologies Membranaires. Tunisia. Journal of Hazardous Materials, 168(2):14171421.

Zhou, Nina. 2010. Parametric Study Of Ultrafiltraion Membrane System and Development of Fouling Control Mechanism.Thesis Master of Science in Engineering. Purdue University. Hammond,Indiana. 